\title{
Medical students' academic motivation: an analysis from the perspective of the Theory of Self-Determination
}

\author{
Motivação acadêmica de estudantes de Medicina: uma análise na perspectiva da Teoria da Autodeterminação \\ Anizio de Almeida Cadête Filho' (1) $\mid$ aniziocadete@gmail.com

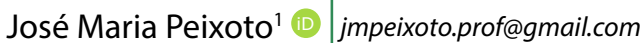 \\ Eliane Perlatto Moura' ${ }^{10}$ | elianeperlatto@gmail.com
}

\begin{abstract}
Introduction: The principles of the Theory of Self-Determination are relevant to professional education, as the differentiation and expression of the primary types of motivation have implications for the multiple learning outcomes.

Objective: To evaluate academic motivation in 4th-year medical students at two teaching institutions and discuss the results from the perspective of the Theory of Self-Determination.

Method:The present is a cross-sectional and quantitative study, conducted through a self-answered questionnaire containing 18 sociodemographic questions and the Academic Motivation Scale (AMS). The sample consisted of 147 4th-year medical students from schools with different teaching methodologies: 73 students from Institution A (Problem-based learning - PBL) and 74 students from Institution B (traditional methodology). A univariate analysis was conducted using Student's t test, Analysis of Variance (ANOVA), chi-square test and Pearson's correlation, followed by Multiple Linear Regression analysis.

Results: There was a moderate profile of intrinsic (IM) and extrinsic (EM) motivation in the sample of students, with a higher IM than EM average. High levels of IM were observed in the domains of motivation for achievement and for knowledge, with the satisfaction of increasing one's knowledge and increasing professional competence being the factors that most positively impacted motivation. In IM, the factor with the lowest score was the university as a place of enjoyment. EM was related to the desire of having a good life in the future, including monetary compensation. It was observed that the variables female gender, age under 23 years, living alone, having attended the entire course at the same institution and school with the PBL methodology had a positive influence on motivation.

Conclusion: The students demonstrated higher levels of IM than those of EM, with a lower score attributed to the university as a place of enjoyment. This fact shows an opportunity for future studies, which will be able to verify the factors of the school environment related to the students' motivation to learn. EM was associated with future life expectations. To know the variables that characterize the self-regulation of learning is crucial to support teaching strategies that contribute to the improvement of the teaching-learning process.
\end{abstract}

Keywords: Motivation; Learning; Medical Education; Medical Students.

\section{RESUMO}

Introdução: Os princípios da Teoria da Autodeterminação são pertinentes para a educação profissional, na medida em que a diferenciação e expressão dos tipos primários de motivação têm implicações para os múltiplos desfechos da aprendizagem.

Objetivo: Este estudo teve como objetivos avaliar a motivação acadêmica em estudantes do quarto ano de Medicina em duas instituições de ensino e discutir os resultados na perspectiva da Teoria da Autodeterminação.

Método: Trata-se de estudo transversal e quantitativo conduzido por questionário autorrespondido contendo 18 questões sociodemográticas e a Escala de Motivação Acadêmica (EMA). A amostra foi constituída por 147 estudantes do quarto ano de Medicina de escolas com metodologias de ensino distintas: 73 estudantes da instituição A (aprendizagem baseada em problemas - ABP) e 74 estudantes da instituição $B$ (tradicional). Conduziu-se uma análise univariada em que se utilizaram os testes t de Student, a Análise de Variância (ANOVA), o teste qui-quadrado e a correlação de Pearson. Posteriormente, fez-se uma análise de regressão linear múltipla.

Resultados: Observou-se um perfil moderado de motivação intrínseca (MI) e extrínseca (ME) na amostra de estudantes, com médias de MI superiores às da ME. Níveis elevados de MI foram observados nos domínios de motivação para realização e para o saber, sendo o prazer de ampliar conhecimentos e o aumento da competência profissional os fatores que mais impactaram positivamente a motivação. Na Ml, o fator com menor pontuação foi a universidade como local de prazer. A ME foi relacionada ao desejo de ter uma boa vida no futuro, incluindo remuneração. Observou-se que as variáveis sexo feminino, idade menor que 23 anos, morar sozinho, ter feito o curso todo na mesma instituição e a escola com metodologia ABP influenciaram de forma positiva na motivação.

Conclusão: Os estudantes demonstraram níveis de MI superiores à da ME, com menor pontuação atribuída à universidade como local de prazer. Esse fato apresenta uma oportunidade para estudos futuros, que poderão verificar os fatores do ambiente escolar que se relacionam à motivação em aprender dos estudantes. A ME foi associada às expectativas futuras de vida. Conhecer as variáveis que caracterizam a autorregulação da aprendizagem é fundamental para embasar estratégias de ensino que contribuam para a melhoria do processo de ensino-aprendizagem.

Palavras-chave: Motivação; Aprendizagem; Educação Médica; Estudantes de Medicina.

1 Universidade José do Rosário Vellano, Belo Horizonte, Minas Gerais, Brazil.

Received on 05/11/20; Accepted on 03/23/21. | Avaliado pelo processo de double blind review. 


\section{INTRODUCTION}

Motivation is a fundamental component of the human performance process $^{1-3}$. Its correlation to the teaching and learning contexts has aroused interest in the literature, as it has predictive power in the school environment, considering that a motivated student is able to transform the acquired knowledge into an incentive for continued learning ${ }^{4}$. Objective or subjective perceptions about the level of personal effectiveness or competence in the academic study environment can affect the intensity or orientation of motivation ${ }^{5}$.

Motivation can be defined as the need or desire linked to the will to meet an expected goal ${ }^{6}$, or as the behavior regulated by the need and instinct to achieve a certain result ${ }^{7}$. According to Pintricch ${ }^{8,9}$, from the academic viewpoint, the motivation to perform a task can be stimulated by three components: (a) a reason or purpose to perform it; (b) the individual's belief in their ability to perform it; and (c) the affective reactions obtained with the performance of the activity.

Two types of motivation can be characterized: the intrinsic motivation, in which something is done for the interest and satisfaction inherent to the action; and extrinsic motivation, in which something is done because of a different consequence or outcome of the action. Extrinsic motivation takes on different forms, which are differentiated by the degree of internalization of values and regulation of conducts, reflecting different levels of autonomy. An autonomous motivation is related to more quality in learning, greater persistence and better learner's psychological adjustment, at any stage of training or schooling ${ }^{10,11}$. That is, extrinsically-motivated behaviors are ruled by the relationship between the prospects of instrumental gains and losses (for instance, incentives), while intrinsicallymotivated behaviors are so for their own good (for instance, the satisfaction of performing the task).

Seeking to understand the motivational determinants and the self-determined forms of motivation, Deci and Ryan ${ }^{12}$ proposed what they called the 'Theory of Self-determination', which differentiates between the distinct levels of motivation: the intrinsic and extrinsic motivation, and the demotivation. The Theory of Self-Determination focuses, particularly, on how one internalizes ideas, values, objectives and intentions under the influence of incorporated social contexts, such as the interaction of the individual with the environment and the context ${ }^{13}$, and it has inspired several studies in the area of education in Brazil ${ }^{14-17}$.

The principle that learning is established through motivation mechanisms is related to the bases of the Theory of Self-Determination. The latter, in turn, understands human behavior as being encouraged by three primary and universal psychological needs for the development of self-determination:
- Autonomy: reflects the desire to participate in activities where the possibility of choice is present;

- Capacity: is related to feeling empowered and confident to perform a certain behavior with a certain aptitude;

- Social relation: it is the need to realize that the behavior is positively recognized by other people, or that its practice facilitates socialization 13 (Figure 1).

The principles of the Theory of Self-Determination are relevant to professional education, as the differentiation and expression of the primary types of motivation have implications for the multiple learning outcomes. Thus, the causality attributions ${ }^{18,19}$, the related concepts, not only to the establishment and achievement of goals ${ }^{20,21}$ but also to the type of motivation (intrinsic or extrinsic) or motivational orientations ${ }^{12}$, constitute important topics to be investigated.

The line of motivational studies related to the university and, more specifically, medical learning, has gained prominence. Hayat, Salehi and Kojuri ${ }^{22}$ observed a positive correlation between intrinsic and extrinsic motivation in the academic performance of medical students at Shiraz University of Medical Sciences. Kusurkar et al. ${ }^{23}$, when studying the motivational profile of sixth-year medical students at the University Medical Center Utrecht, observed a positive correlation between intrinsic motivation and adequate study strategies, hours of self-study and academic performance and a negative correlation with exhaustion. Sobral et al. ${ }^{24}$ observed distinct patterns of intrinsic and extrinsic motivation (also called autonomous and controlled, respectively) that seem to be related to the perception of medical students in relation to learning, as well as the educational environment.

According to Lozano et al. ${ }^{25}$ in a dynamic motivational model, a "motivated student" considers the proposed educational activities to be useful or interesting (perception of an educational activity value), feels able to complete the

Figure 1. Needs that encourage behavior through the Theory of Self-Determination.

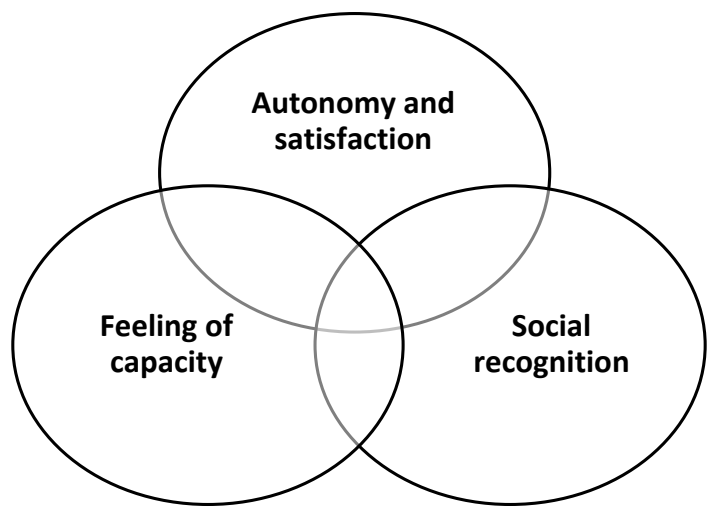


activities for their own satisfaction (perceived self-efficacy) and has the impression of being responsible for the progress of their learning (perception of controllability).

Considering the importance of the motivation construct for the learning process in medical education and its relationship with the Theory of Self-Determination, this study aimed to assess academic motivation in 4th-year medical students at two teaching institutions in the city of Belo Horizonte, state of Minas Gerais (MG), Brazil, and discuss the results from the viewpoint of the Theory of Self-Determination. The results of this study can be used as parameters for the development of interventions that might have an impact on medical students' learning.

\section{METHOD}

The present is a cross-sectional and quantitative study conducted through a self-answered questionnaire, aiming to assess medical students' motivation. The sample consisted of 147 fourth-year medical students from two private educational institutions located in Belo Horizonte - MG, which used different teaching methodologies, with 73 students from Institution A (Problem-Based Learning [PBL] methodology) and 74 students from Institution B (Traditional methodology). This sample represented, respectively $44.2 \%$ and $55.2 \%$ of the total number of medical students enrolled in the fourth year at institutions A and B. The fourth year of medical school was chosen because it is the last period in which the two courses show differences in their teaching methodologies. As of this period, the internship begins, when the teaching activities start to show greater homogeneity in both institutions, since they are characterized by practical activities in health services. Up to this point in the course, the two institutions have differences in their methodologies, and in the institution with the traditional methodology, the transition from the teaching of the topics of the basic areas to the practice ones is more defined, when compared to the proposal of the curriculum guided by the PBL, where these activities occur simultaneously. The sampling was determined by convenience among students who were attending the fourth year of medical school and were present in the classroom when the questionnaire was applied. The invitation was made by the researchers in the classrooms, at a predetermined time with the teacher, followed by the completion of the questionnaire by the students who agreed to participate and signed the informed consent form. The research instrument contained 46 questions, 18 of which were sociodemographic assessment questions to identify behavioral, health, family and educational environment factors, developed by the researchers and 28 questions from the Academic Motivation Scale (AMS) prepared by Vallerand et al. ${ }^{26}$ and validated for the Portuguese language by Sobral ${ }^{24}$. This scale was chosen due to the large number of citations in the literature. The time needed for filling out the questionnaire was freely determined by the students, but it lasted an average of 20 minutes.

- Sociodemographic questionnaire: The questionnaire consisted of 18 sociodemographic, academic and family-related questions. The following variables were analyzed: name, gender, age, family income, having a first-degree relative who was a physician, marital status, living alone or with family, having paid work, number of weekly hours worked, having any health problems, antidepressant medication use, chronic medication use, having completed the entire course at the institution, being regularly enrolled in the course, having an extracurricular activity and the main reason for the extracurricular activity.

- Academic Motivation Scale(AMS):The original version of the scale was developed in the French language of Canada by Vallerand et al.26, assuming the multifactorial nature of motivational processes and translated and adapted into Brazilian Portuguese by Sobral24. It consists of 28 items and scored using a seven-point Likert scale ( $1=$ no match and $7=$ total match). The scale has seven dimensions and aims at measuring three types of Intrinsic Motivation (IM) and three types of Extrinsic Motivation (EM), in addition to demotivation (Charts 1, 2 and 3).

The types of intrinsic motivation include: intrinsic motivation to know something (to do something for the pleasure that comes from learning, exploring or understanding); intrinsic motivation to accomplish things (do something for the satisfaction that results from the search to accomplish or create things) and intrinsic motivation to experience stimulation (do something aiming to experience stimulating sensations, of a sensory or aesthetic nature). The types of extrinsic motivation include: regulation by identification (do something because one decided to do it); introjection regulation (do something because one pressure themselves to do it); external regulation (do something because one feels pressured by others to do it). Finally, the concept of demotivation implies a lack of perception of contingencies between actions and their outcomes (lack of intrinsic or extrinsic reasons). The analysis of the types of motivation followed the parameters described by Lopes et al28 (Charts 1, 2 and 3).

The items shown in Tables 1 to 3 were analyzed through the scores obtained using the Likert scale, with a score ranging from 1 to 7. Therefore, adapted from the study by Azevedo et al. ${ }^{27}$, the following cutoff points were used: $\leq 3.0$ (low 
motivation); $>3.0$ and $<6.0$ (average motivation); and $\geq 6.0$ (high motivation).

Academic performance was measured by the overall average of the obtained grades taking into account all subjects taken up to the moment of the study, which were made available by the institutions.

The average of the sum of the scores of the 28 items of the AMS was used to evaluate the academic motivation in each institution (total score) and the average scores of the items related to each of the dimensions, to evaluate the students' motivation in each instrument domain. For data analysis, descriptive statistics were performed and a univariate analysis was conducted using Student's $t$ test and/or Analysis of Variance (ANOVA), chi-square test and Pearson's correlation, with the purpose of pre-selecting the variables of interest to conduct the multivariate analysis, to which the Multiple Linear Regression analysis was applied. The level of significance was set at $5 \%(p<0.05)$. The software SPSS 14.0 for Windows (Statistical Software) was used.

Ethical Considerations: The project was sent to the

Chart 1. Intrinsic motivation for

\begin{tabular}{|c|c|}
\hline knowledge & $\begin{array}{l}\text { - because I feel satisfaction and joy while learning new things } \\
\text { - for the joy of discovering new things that l've never seen or known before } \\
\text { - for my satisfaction in increasing my knowledge on subjects that attract me } \\
\text { - because my studies allow me to continue to learn about many things that interest me }\end{array}$ \\
\hline performance & $\begin{array}{l}\text { - } \text { because I think university education helps me to prepare better for the career I have chosen } \\
\text { - because the course will enable me, in the end, to enter the job market in an area that I like } \\
\text { - because it will help me choose my career guidance better } \\
\text { - } \quad \text { because I believe that university education will increase my competence as a professional }\end{array}$ \\
\hline stimulation experience & $\begin{array}{l}\text { - } \text { because I really like coming to the university } \\
\text { - because for me the university is a joy } \\
\text { - for the satisfaction I get when engaging in debates with interesting teachers } \\
\text { - for the euphoria I feel when I read about several interesting subjects }\end{array}$ \\
\hline
\end{tabular}

Chart 2. Extrinsic motivation for

\begin{tabular}{ccc}
\hline & for the satisfaction I feel when I surpass myself during study \\
identification & - & for the satisfaction I feel when I surpass myself in some of my personal achievements \\
& - & for the satisfaction I feel when I am in the process of carrying out difficult academic activities \\
regulation & because the university allows me to feel a personal satisfaction in my search for excellence in training \\
\hline and introjection & - & to prove to myself that I am able to complete the course \\
& - & because I feel important when I am successful at the university \\
& - & because I want to show myself that I can succeed in my studies \\
\hline & - & in order to get a prestigious job in the future \\
external regulation & because I want to have a good life in the future \\
& - & in order to have a good remuneration in the future
\end{tabular}

\section{Chart 3. Demotivation.}

- Honestly, I don't know; I think I'm wasting my time at the university

- I already had good reasons for that; now, however I wonder if I should continue

- I don't know (understand) why I am coming to university and, frankly, I do not worry about that

- I don't know; I don't understand what I'm doing at the university 
Research Ethics Committee of Universidade José do Rosário Vellano, having received a favorable opinion, under CAAE number 84589418.5.0000.5143.

\section{RESULTS}

The study involved 147 students who were attending the fourth year of medical school at two educational institutions located in Belo Horizonte-MG. Overall, these were the characteristics of the participants: most were females (70\%); age group 19 to 30 years, predominance of family income higher than $\mathrm{R} \$ 10,000.00$ (63\%); not having a relative who was a physician (69\%), being single (96\%), not having paid work (97\%), not having a health problem (80\%); not using antidepressant medication (82\%) or for chronic diseases (82\%), not being a smoker (97\%), not having changed educational institutions during the medical course (85\%); having an extracurricular activity (82\%) and be regularly attending the course (94\%).

The analysis of the academic motivation scores of the 147 students showed an average intrinsic motivation score higher than that observed for extrinsic motivation (Table 1). In the individual assessment of the items that constitute the AMS, in relation to intrinsic motivation, it was observed that the domain of "intrinsic motivation for achievement" obtained the highest average score; while the items that received the highest score were those related to the perception that university education better prepares someone for the career one has chosen and increases professional competence, the item that received the lowest score was the one about the influence of the university on the choice of professional orientation. In the domain of "intrinsic motivation to know", the item with the

Table 1. Average motivation scores of $4^{\text {th }}$-year medical students assessed by the Academic Motivation Scale (AMS), 2018.

\begin{tabular}{ccc}
\hline Domains & $\begin{array}{c}\text { Score } \\
(\text { mean } / \mathbf{s d})\end{array}$ & $\mathbf{p}^{*}$ \\
\hline Intrinsic motivation (IM) & $5.9 \pm 0.7^{*}$ & $<0.001$ \\
IM for knowledge & $6.0 \pm 1.1$ & \\
IM for achievement & $6.3 \pm 0.9$ & \\
IM for stimulation & & \\
$\quad$ experience & $4.5 \pm 1.4$ & \\
Extrinsic motivation (EM) & $5.3 \pm 1.2^{*}$ & \\
EM for identification & $5.0 \pm 1.6$ & \\
EM for introjection & $4.1 \pm 1.7$ & \\
EM for external control & $5.7 \pm 1.2$ & \\
Demotivation & $1.6 \pm 1.1^{*}$ &
\end{tabular}

Database: 147 students.

Note: the probability of significance refers to the Student's t-test for paired samples $\left(p^{*}\right)$. highest score was the satisfaction of increasing knowledge on attractive subjects and the one with the lowest score was the joy of discovering new things. The domain of "intrinsic motivation to experience stimulation" was the one with the lowest average score, and in this, the item related to reading interesting subjects was the one with highest score, while the item that considers the university a joy showed the lowest score.

Regarding extrinsic motivation, the domain of "extrinsic motivation for external control" obtained the highest average score, with the highest scores for the items related to having a good life and a good remuneration in the future, while having a prestigious career received the lowest score. In the domain of "extrinsic motivation for identification", the item with the highest score was the satisfaction of surpassing personal achievements and the one with the lowest score was the satisfaction with the accomplishment of difficult academic activities. The domain of "extrinsic motivation for introjection", obtained the lowest average, whereas the item with the highest score was related to showing oneself that one can be successful in their studies, whereas the one with the lowest score was showing oneself that you are an intelligent person. In the domain of demotivation, the item with the highest score was not seeing a reason to continue attending the course.

In this study, the sociodemographic, academic and family factors that influenced the motivation scores obtained by AMS were: gender, age, living alone, taking antidepressant medication, not attending the entire course at the same institution and the teaching methodology used by the institution (Table 2). The female gender had higher average scores in the majority of the domains of the motivation scales $(p<0.05)$, with the exception of extrinsic motivation for external control and demotivation, where the average scores were similar between the genders $(p>0.05)$. A significant and weak negative correlation $(r=-0.19-p<0.029)$ was identified between age in the extrinsic motivation subscale for external control, in which younger students tend to show superior results. Students who live alone showed superior results $(p<0.05)$ in the subscales intrinsic motivation to know and to experience stimulation and extrinsic motivation for identification when compared with students living with the family. Students who used antidepressant medication showed higher values ( $p$ $<0.05$ ) in the subscale that evaluates demotivation. Students from the institution with PBL methodology showed higher values of intrinsic and extrinsic motivation in all domains of the scale, except for extrinsic motivation for external control, which was similar in both institutions. It is noteworthy that the demotivation domain had a higher score in the institution with traditional methodology. 
Table 2. Influence of sociodemographic, family and academic factors on the average motivation score measured by the Academic Motivation Scale in medical students - BH, 2018.

\begin{tabular}{|c|c|c|c|c|c|c|c|c|c|c|c|c|c|c|}
\hline \multirow{3}{*}{ Variables } & \multicolumn{14}{|c|}{ Domains } \\
\hline & \multirow{2}{*}{$\begin{array}{c}\text { IM } \\
\text { knowledge }\end{array}$} & \multirow[t]{2}{*}{ p } & \multirow{2}{*}{$\begin{array}{c}\text { IM } \\
\text { achievement } \\
\text { mean } \pm \text { sd }\end{array}$} & \multirow[t]{2}{*}{$\mathbf{p}$} & \multirow{2}{*}{ 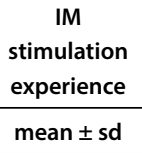 } & \multirow[t]{2}{*}{ p } & \multirow{2}{*}{$\begin{array}{c}\text { EM } \\
\text { identification } \\
\text { mean } \pm \mathrm{sd}\end{array}$} & \multirow[t]{2}{*}{$p$} & \multirow{2}{*}{$\begin{array}{c}\mathrm{EM} \\
\text { introjection } \\
\text { mean } \pm \mathrm{sd}\end{array}$} & \multirow[t]{2}{*}{$\mathrm{p}$} & $\begin{array}{c}\text { EM } \\
\text { external } \\
\text { control }\end{array}$ & \multirow[t]{2}{*}{ p } & \multirow{2}{*}{$\begin{array}{c}\text { Demotivation } \\
\text { mean } \pm \mathrm{sd}\end{array}$} & \multirow[t]{2}{*}{$\mathbf{p}$} \\
\hline & & & & & & & & & & & mean $\pm s d$ & & & \\
\hline \multicolumn{15}{|l|}{ Gender } \\
\hline Female & $5.4 \pm 1.3$ & 0.001 & $5.8 \pm 1.1$ & 0.002 & $3.8 \pm 1.3$ & $<0.001$ & $4.2 \pm 1.6$ & $<0.001$ & $3.6 \pm 1.9$ & 0.031 & $5.6 \pm 1.4$ & 0.511 & $1.9 \pm 1.2$ & 0.073 \\
\hline Male & $6.2 \pm 1.0$ & & $6.4 \pm 0.8$ & & $4.8 \pm 1.3$ & & $5.3 \pm 1.5$ & & $4.3 \pm 1.6$ & & $5.7 \pm 1.1$ & & $1.5 \pm 1.0$ & \\
\hline \multicolumn{15}{|l|}{ Age } \\
\hline r & 0.07 & 0.424 & -0.09 & 0.270 & 0.05 & 0.584 & -0.02 & 0.0 .73 & -0.13 & 0.144 & -0.19 & 0.029 & -0.05 & 0.598 \\
\hline \multicolumn{15}{|c|}{ Family income (R\$) } \\
\hline \multicolumn{15}{|l|}{ Up to } \\
\hline $\begin{array}{l}5,000,00 \\
\text { reais }\end{array}$ & $6.5 \pm 0.4$ & 0.394 & $6.5 \pm 0.6$ & 0.773 & $4.9 \pm 1.5$ & 0.407 & $5.3 \pm 1.3$ & 0.212 & $4.8 \pm 1.1$ & 0.210 & $6.3 \pm 0.7$ & 0.391 & $1.5 \pm 0.6$ & 0.469 \\
\hline $\begin{array}{c}>5,000,00 \\
\text { reais }\end{array}$ & $6.2 \pm 0.8$ & & $6.4 \pm 0.7$ & & $4.8 \pm 1.3$ & & $4.8 \pm 1.6$ & & $4.1 \pm 1.5$ & & $5.6 \pm 1.4$ & & $1.5 \pm 1.0$ & \\
\hline \multicolumn{15}{|c|}{ Relative who is a physician } \\
\hline Yes & $5.8 \pm 1.3$ & 0.306 & $6.1 \pm 1.0$ & 0.312 & $4.3 \pm 1.3$ & 0.113 & $4.8 \pm 1.7$ & 0.337 & $4.3 \pm 1.7$ & 0.408 & $5.7 \pm 1.4$ & 0.943 & $1.8 \pm 1.2$ & 0.303 \\
\hline No & $6.1 \pm 1.1$ & & $6.3 \pm 0.9$ & & $4.6 \pm 1.4$ & & $5.1 \pm 1.5$ & & $4.0 \pm 1.7$ & & $5.7 \pm 1.1$ & & $1.6 \pm 1.0$ & \\
\hline \multicolumn{15}{|l|}{ Lives alone } \\
\hline Yes & $6.2 \pm 1.0$ & 0.029 & $6.4 \pm 0.8$ & 0.056 & $4.8 \pm 1.3$ & 0.010 & $5.4 \pm 1.5$ & 0.006 & $4.3 \pm 1.6$ & 0.130 & $5.7 \pm 1.2$ & 0.684 & $1.5 \pm 0.8$ & 0.059 \\
\hline No & $5.8 \pm 1.3$ & & $6.1 \pm 1.0$ & & $4.3 \pm 1.4$ & & $4.6 \pm 1.6$ & & $3.9 \pm 1.7$ & & $5.7 \pm 1.2$ & & $1.8 \pm 1.3$ & \\
\hline \multicolumn{15}{|c|}{ Health problems } \\
\hline Yes & $6.0 \pm 1.1$ & 0.748 & $6.1 \pm 0.7$ & 0.353 & $4.9 \pm 1.2$ & 0.047 & $5.2 \pm 1.6$ & 0.412 & $4.5 \pm 1.7$ & 0.211 & $5.8 \pm 1.0$ & 0.577 & $1.7 \pm 0.8$ & 0.790 \\
\hline No & $6.0 \pm 1.2$ & & $6.3 \pm 1.0$ & & $4.4 \pm 1.4$ & & $4.9 \pm 1.6$ & & $4.0 \pm 1.7$ & & $5.7 \pm 1.2$ & & $1.6 \pm 1.1$ & \\
\hline \multicolumn{15}{|c|}{ Antidepressant medication } \\
\hline Yes & $5.7 \pm 1.4$ & 0.291 & $5.9 \pm 1.0$ & 0.065 & $4.4 \pm 1.6$ & 0.575 & $4.6 \pm 1.8$ & 0.193 & $4.0 \pm 1.6$ & 0.725 & $5.8 \pm 1.1$ & 0.798 & $2.1 \pm 1.1$ & 0.012 \\
\hline No & $6.0 \pm 1.1$ & & $6.3 \pm 0.9$ & & $4.6 \pm 1.3$ & & $5.1 \pm 1.5$ & & $4.1 \pm 1.7$ & & $5.7 \pm 1.2$ & & $1.5 \pm 1.0$ & \\
\hline \multicolumn{15}{|c|}{ Medication for chronic disease } \\
\hline Yes & $5.9 \pm 1.1$ & 0.792 & $6.2 \pm 0.6$ & 0.574 & $4.9 \pm 1.2$ & 0.110 & $5.0 \pm 1.6$ & 0.899 & $4.4 \pm 1.7$ & 0.284 & $5.9 \pm 0.9$ & 0.291 & $1.9 \pm 1.1$ & 0.182 \\
\hline No & $6.0 \pm 1.2$ & & $6.3 \pm 1.0$ & & $4.4 \pm 1.4$ & & $5.0 \pm 1.6$ & & $4.0 \pm 1.7$ & & $5.7 \pm 1.2$ & & $1.6 \pm 1.1$ & \\
\hline Attended e & tire course at & he instit & tion & & & & & & & & & & & \\
\hline Yes & $6.0 \pm 1.1$ & 0.692 & $6.3 \pm 0.9$ & 0.335 & $4.5 \pm 1.3$ & 0.877 & $4.9 \pm 1.6$ & 0.778 & $4.3 \pm 1.7$ & 0.011 & $5.7 \pm 1.2$ & 0.937 & $1.6 \pm 1.0$ & 0.739 \\
\hline No & $6.1 \pm 1.4$ & & $6.1 \pm 1.1$ & & $4.6 \pm 1.6$ & & $5.1 \pm 1.7$ & & $3.3 \pm 1.5$ & & $5.7 \vee 1.2$ & & $1.7 \pm 1.4$ & \\
\hline Extracurricl & ar activity & & & & & & & & & & & & & \\
\hline Yes & $6.0 \pm 1.1$ & 0.588 & $6.3 \pm 0.9$ & 0.751 & $4.5 \pm 1.4$ & 0.909 & $5.0 \pm 1.6$ & 0.346 & $4.1 \pm 1.7$ & 0.588 & $5.8 \pm 1.1$ & 0.142 & $1.6 \pm 1.0$ & 0.337 \\
\hline No & $5.9 \pm 1.2$ & & $6.2 \pm 0.9$ & & $4.5 \pm 1.5$ & & $4.7 \pm 1.7$ & & $4.3 \pm 1.6$ & & $5.3 \pm 1.4$ & & $1.9 \pm 1.4$ & \\
\hline Academic $p$ & erformance & & & & & & & & & & & & & \\
\hline$r$ & 0.02 & 0.847 & -0.03 & 0.695 & 0.05 & 0.566 & -0.03 & 0.703 & -0.16 & 0.052 & -0.08 & 0.338 & -0.1 & 0.206 \\
\hline
\end{tabular}

Database: 147 students.

IM- intrinsic motivation; EM- extrinsic motivation. The probability of significance refers to the Student's $t$ test, Analysis of variance and correlation analysis.

\section{DISCUSSION}

The aim of this study was to evaluate the academic motivation of students attending the 4 th year of medical school at two educational institutions in Belo Horizonte, state of MG, Brazil, and to discuss the results from the perspective of theTheory of Self-Determination. The results obtained by the Academic Motivation Scale disclosed moderate levels of intrinsic and extrinsic motivation, with the IM averages being higher than the
EM ones. It is noteworthy that high levels of intrinsic motivation were observed in the domains of motivation for achievement and knowledge, with the satisfaction of increasing knowledge on attractive topics and increasing professional competence being the factors that most positively impacted the analyzed students' motivation. However, low scores were observed in the item attending the university for one's enjoyment. The extrinsic motivation was related to the desire to have a good life and a 
good remuneration in the future.

The intrinsic motivation predominance reveals that what motivates students the most is the enjoyment of the activity in itself. The data obtained in the present study are in line with the results of previous studies regarding the predominance of intrinsic motivation in university students, both in the medical course ${ }^{15}$ and in other courses in the biological, human and exact sciences areas ${ }^{14,28,29}$.

The fact that intrinsic motivation predominates in the group of assessed students is an expected and positive fact in both institutions that were part of this study, because according to the Theory of Self-determination, human beings are naturally inclined towards personal development, seeking to internalize psychological and social elements that favor the construction of a sense of self ${ }^{30}$, with the intrinsic motivation being the phenomenon that best represents the positive potential of human nature, configuring itself as a natural tendency to exercise their own capacities, seeking innovations and challenges.

It refers to involvement in a given activity for its own sake, because it is interesting, engaging or somehow generating satisfaction, promoting students' greater interest in learning and confidence in their own capacities and attributes ${ }^{16,31}$. Thus, intrinsic motivation represents the best type of motivation, as it is autonomous or self-determined. The students' curiosity and personal interest in the learning material lead to knowledge that is characterized by a sense of psychological freedom and an internal locus of causality ${ }^{31}$, which can be demonstrated in this study by the high average scores observed in the domains of intrinsic motivation for achievement (which refers to the interaction with the environment and the feeling of competence to create) and in the domain of motivation for knowledge (which is related to exploration, curiosity and objectives). Intrinsic motivation leads to the creation of internal goals, called learning objectives ${ }^{32}$, unlike the external or performance goals that guide extrinsic motivation, aiming at receiving rewards or the absence of punishment ${ }^{32}$. Students guided by learning objectives pursue more often the development of their skills, while those guided by performance goals pursue the obtaining of positive evaluations ${ }^{32}$.

An interesting evidence observed in this study is that among the components of intrinsic motivation, the one that obtained the lowest score in the students' self-perception of motivation was the item associating the university to a place of enjoyment. The literature points out several factors related to the school environment capable of influencing the motivation for learning, and among them, one of the most important is what occurs in the classroom, from the didactic materials used, the teaching methodology employed and the affective factors seen in teacher-student relationship ${ }^{33,34}$. The classroom should be an pleasant place, providing the student with a sense of belonging, with motivation being mediated by the teacher, the classroom environment and the school culture ${ }^{31}$.

Since motivation is influenced by the interaction of intrinsicand extrinsiccomponents $\mathrm{s}^{34}$, the possibility of awakening the student's motivation by the university, associating it as a place of enjoyment, is an important contribution identified in this study, which highlights the opportunity for teachers and managers to plan methodological, training actions and those related to the educational environment itself, which provide stimulating experiences for students.

Despite the predominance of the intrinsic motivation in the assessed students, the extrinsic component, regulated by rewards and restrictions, was also present. According to Boruchovitch ${ }^{28}$ and Ryan and Deci ${ }^{33}$, the presence of the extrinsic orientation, related to behaviors that are used as a means to an end and not by themselves, can also produce good results in learning when accompanied by the intrinsic motivation.

In the domain of extrinsic motivation, the highest scores were observed in items related to future life expectations, including remuneration and those related to the satisfaction of surpassing oneself for personal achievements, and the lowest ones for difficult and academic activities and obtaining a prestigious job. It can be observed, therefore, that the items that most mobilize the extrinsic motivation are those related to the satisfaction of personal desires, the achievement of autonomy and those that arouse the student's interest more for the identification than for the obligation to do something. After all, human motivation is guided by the need for selfaccomplishment, which considers the meeting of basic needs, including security and esteem ${ }^{35}$. Our data showed that students recognize the university as the best means of preparation for their chosen career, which confirms the proposition that the need for academic training is a reflection of the desire to develop as an individual ${ }^{35}$.

It is important to point out that although the extrinsic component of motivation is relevant for learning, it must be used with the aim of awakening the intrinsic motivation, which is associated with a high degree of academic performance and student satisfaction ${ }^{36}$; the use of extrinsic rewards without planning can promote a reduction in intrinsic motivation, as it does not awaken in the student the satisfaction of learning for learning's sake ${ }^{37}$.

Knowledge of the students' motivational goals and orientations is important, as they support the motivational sequence triggered when they are faced with a task to be performed, with an impacton learning ${ }^{28}$. The type of motivational orientation of students has been associated with differences 
in the variables: gender, age, semester, characteristics of the educational institution, beliefs, perception of a future time, among others ${ }^{28}$. Orsini et al. ${ }^{38}$ conducted a systematic review of factors that influence motivation and categorized them into five groups: 1) intrapersonal determinants, such as age and gender; 2) interpersonal determinants, such as academic conditions; 3) cognitive results, such as beliefs; 4) affective results, such as anxiety or depression; and 5) behavioral results, such as academic involvement. The choice, the recognition of feelings and the opportunity for self-direction also increased intrinsic motivation, because these factors facilitated a greater sense of autonomy ${ }^{39}$. Therefore, the analysis of the influence of students' sociodemographic variables is important, as they have implications both in their academic and social integration process, either in their short-, medium- and long-term academic and professional trajectories ${ }^{40}$.

Inlinewith what wasobserved byother researchers ${ }^{16,24,41,42}$, the results of the present study showed that female students had higher average motivation scores when compared to male students. Regarding age, it was observed that younger students had a higher score in extrinsic motivation, which does not corroborate the findings of the literature, since some studies did not find an association between age and motivation, while in others, older students showed a more autonomous profile ${ }^{43-45}$. Unlike the results obtained by Azevedo ${ }^{27}$, it was observed that students who lived without their parents had higher levels of motivation. In an attempt to explain this fact, one can infer that the new social reality experienced by students who are far from their families stimulates the development of autonomy, which is one of the bases of the Theory of Self-Determination. Another important finding was the absence of a relationship between academic performance and the degree of motivation, which reinforces the assessed students' self-determined motivation.

Finally, it was observed that the students attending the institution that adopts the PBL methodology had higher mean AMS scores in comparison to those attending the school using the traditional methodology. This fact can be explained in the light of the Theory of Self-Determination, which establishes autonomy, competence and relationship as pillars of motivation ${ }^{10}$, aspects favored by the PBL methodology ${ }^{39,46}$. According to the conception developed by Ryan and Deci ${ }^{33}$, the academic environment is preponderant, since it can facilitate or inhibit the intrinsic motivation, due to the support or obstruction of the psychological needs of the students' competence and autonomy. According to Reeve ${ }^{47}$, students who perceive themselves as autonomous in their school interactions show positive results in relation to motivation, commitment, development, learning, performance improvement and psychological status. Thus, a context that encourages autonomy is beneficial to learning and performance, with an effect on motivation, the internalization of values and rules, which will provide people with greater self-determination. However, it is not possible to state, based on these data, that the PBL methodology would be able to individually influence the students' motivation, since this study did not aim to compare the two educational institutions regarding the different variables related to students' motivation.

Despite the natural tendency that students have for personal development, it is important to note that external factors can make it difficult for intrinsic motivation to fully manifest ${ }^{30}$. Aiming at favoring intrinsic motivation, the teaching should encourage the medical students' autonomy, with the planning of activities arising from the students' needs, with opportune challenges set at their cognitive level, encouraging active participation and the development of responsibility for their own learning, in addition to providing emotional support and constructive feedback ${ }^{48}$.

Knowing that motivation comprises dynamic states and not stable personality traits ${ }^{49,50}$, as limitations of the study, we can mention:

- As its cross-sectional methodology prevents its results to be generalized, longitudinal studies are necessary for obtain better knowledge of the students' motivation profile throughout the course, as well as the influence of sociodemographic factors on this trajectory.

- The use of a self-report scale, which carries the risk of response subjectivity due to the effect of social desirability.

- This study did not evaluate the school environment factors related to student motivation, which can be explored in future studies.

- The study did not compare educational institutions aiming to verify whether the employed teaching methodology is associated to student motivation, and future studies can further this knowledge.

This study contributes to encourage the discussion of the need to consider beyond the curricular cognitive elements, one of the most important aspects related to learning, i.e., motivation, since it is related to deep learning and promotes the habit of learning throughout one's professional life, providing the training of competent professionals. Considering that motivation and learning are fully related in the academic environment, it is important for the topic to be considered by managers and teachers when planning academic activities, including the curricular organization, which should consider strategies to meet the students' autonomy needs, promoting 
feelings of confidence in their skills and social relationships, which are the basic needs defended by the Theory of SelfDetermination $^{51}$.

\section{CONCLUSION}

This study showed that fourth-year medical students had a moderate profile of intrinsic and extrinsic motivation, with higher averages of intrinsic motivation than the extrinsic ones. The high levels of intrinsic motivation were observed in the domains of motivation for achievement and knowledge, with the satisfaction of increasing knowledge and professional competence being the factors that most positively impacted the students' motivation. Among the factors of intrinsic motivation, the one that received the lowest score was the university as a place of enjoyment. This fact presents an opportunity for future studies, which will be able to verify the factors of the school environment that are associated to the students' motivation to learn. Extrinsic motivation showed to be highly associated with the desire to have a good life in the future, including good remuneration. Academic motivation was influenced by the following factors: female gender, living alone and studying at an institution that applied the PBL methodology. Knowing the variables that characterize the self-regulation of learning is essential to support teaching strategies that contribute to the improvement of the teaching-learning process.

\section{AUTHORS' CONTRIBUTIONS}

Anizio de Almeida Cadête Filho actively participated in the study design, data collection; discussion of results and the writing of the manuscript. These are the results of the Master's Degree dissertation. José Maria Peixoto participated in the review and approval of the final version of the manuscript. Eliane Perlatto Moura actively participated in the study design, data collection, discussion of results, writing of the manuscript, review and approval of the final version of the text.

\section{CONFLICTS OF INTEREST}

The authors declare no conflicts of interest related to this study.

\section{FUNDING}

The authors declare that there were no external sources of funding for this study.

\section{REFERENCES}

1. Campbell JP, Pritchard RD. Motivation theory in industrial and organizational psychology. In: Dunnette MD, Hough L, editors. Handbook of industrial and organizational psychology. Chicago: Rand McNally College; 1976. p. 63-130.

2. Maier NRF. Psychology in industry. 2nd ed. Boston: Houghton Mifflin; 1955.

3. Pinder WCC. Work motivation in organizational behavior. 2nd ed. New York: Psychology Press; 2011.
4. Spinath B. Development and modification of motivation and selfregulation in school contexts: introduction to the special issue. Learn Instr. 2005;15(2):85-6.

5. Ryan RM, Deci EL. Intrinsic and extrinsic motivations: classic definitions and new directions. Contemp Educ Psychol. 2000;25(1):54-67.

6. Todorov JC, Moreira MB. O conceito de motivação na psicologia. Rev Bras Ter Comport Gogn. 2005;7(1):119-32.

7. Deese J. Principles of psychology. Boston: Allyn and Bacon, 1964.

8. Pintrich PR. Editor's comment. Educ Psychol. 1991;26(3-4):199-205.

9. Pintrich PR. The role of goal orientation in self-regulated learning. In: Boekaerts M, Pintrich PR, Zeidner M. Handbook of self-regulation. Cambridge: Academic Press; 2000. p. 451-502.

10. Deci EL, Vallerand RJ, Pelletier LG, Ryan RM. Motivation and education: the self-determination perspective. Educ Psychol. 1991;26(3-4):325-46.

11. Deci EL, Ryan RM, Williams GC. Need satisfaction and the self-regulation of learning. Learn Individ Differ. 1996;8(3):165-83.

12. Deci EL, Ryan RM. The general causality orientations scale: selfdetermination in personality. J Res Pers. 1985;19(2):109-34.

13. Deci EL, Ryan RM. Motivation, personality, and development within embedded social contexts: an overview of self-determination theory. In: Deci EL, Ryan RM. The Oxford handbook of human motivation. Rochester: University of Rochester; 2012. p. 85-107.

14. Lopes LMS, Pinheiro FMG, Silva ACR, Abreu ES. Aspectos da motivação intrínseca e extrínseca: uma análise com discentes de ciências contábeis da Bahia na perspectiva da teoria da autodeterminação. RGFC. 2015;5(1):21-39.

15. Sobral DT. Motivação do aprendiz de medicina: uso da escala de motivação acadêmica. Psicol Teor Pesqui. 2003;19(1):25-31.

16. Guimarães SER, Bzuneck JA, Boruchovitch E. Estilos motivacionais de professores: propriedades psicométricas de um instrumento de avaliação. Psicol Teor Pesqui. 2003;19(1):17-24.

17. Guimarães SEF, Boruchovitch E. O estilo motivacional do professor e a motivação intrínseca dos estudantes: uma perspectiva da teoria da autodeterminação. Piscol Reflex Crit. 2004;17(2):143-50.

18. Weiner, B. A theory of motivation for some classroom experiences. J Educ Psychol. 1979;71(1):3-25.

19. Weiner, B. Transforming cultural plurality into theoretical unity. In: Mcinerney MD, Van Etten, S, editors. Big theories revisited. Greenwich Information Age; 2004. p. 13-29.

20. Nicholls JG. Achievement motivation: conceptions of ability, subjective experience, task choice, and performance. Psychol Rev. 1984;91(3):328-46.

21. Elliot ES, Dweck CS. Goals: an approach to motivation and achievement. J Pers Soc Psychol. 1988;54(1):5-12.

22. Hayat AA, Salehi A, Kojuri J. Medical student's academic performance: the role of academic emotions and motivation. J Adv Med Educ Prof. 2018;6(4):168-75.

23. Kusurkar RA, Croiset G, Galindo-Garré F, Ten Cate O. Motivational profiles of medical students: association with study effort, academic performance and exhaustion. BMC Med Educ. 2013;13(1):87-95.

24. Sobral DT What kind of motivation drives medical students' learning quests? Med Educ. 2004;38(9):950-7.

25. Lozano AB, Mascarenhas SA, Castro FV, Rioboo AP. Motivação académica e atribuições causais: a escala QEAP48 numa amostra de alunos universitários de Rondônia e Humaitá (Amazónia, Brasil). Actas do X Congresso internacional Galeco-Português de Psicopedagogia. Braga: Universidade do Minho; 2009 p. 4497-508.

26. Vallerand RJ, Pelletier L, Blais MR, Brière NM. The academic motivation scale: a measure of intrinsic extrinsic and amotivation in education. Educ Pshycol Measu 1992;52(4):1003-17.

27. Azevedo PTÁCC, Caminha MDF, Andrade CRSD, Godoy CGD, Monteiro RLS, Falbo AR. Motivação Intrínseca do Estudante de Medicina de uma faculdade com metodologia ativa no Brasil: estudo transversal. Rev Bras Educ Med. 2019;43(1):12-23. 
28. Boruchovitch E. A motivação para aprender de estudantes em curso de formação de professores. Educ 2008;31(1):30-8.

29. Joly MCRA, Prates EAR. Avaliação da escala de motivação acadêmica em estudantes paulistas: propriedades psicométricas. Psico USF. 2011;16(2):175-84

30. Ten Cate TJ, Kusurkar RA, Williams GC. How self-determination theory can assist our understanding of the teaching and learning processes in medical education. Med Teach. 2011;33(12):961-73.

31. Vansteenkiste M, Sierens E, Soenens B, Luyckx K, Lens W. Motivational profiles from a self-determination perspective: the quality of motivation matters. J Educ Psychol. 2009;101(3):671-88.

32. Ribeiro F. Motivação e aprendizagem em contexto escolar. Profforma. 2011;03:1-5 [access in 26 apr 2020]. Available from: http://www.cefopna. edu.pt/revista/revista_03/pdf_03/es_05_03.pdf.2:

33. Ryan RM, Deci EL. Self-determination theory and the facilitation of intrinsic motivation, social development, and well-being. Am Psychol. 2000;55(1):68-78.

34. Lourenço AA, de Paiva MOA. A motivação escolar e o processo de aprendizagem. Ciência \& Cognição. 2010;15(2):132-41.

35. Kusurkar RA, Croiset G, Mann KV, Custers E, Ten Cat O. Have motivation theories guided the development and reform of medical education curricula? A review of the literature. Med Acad. 2012;87(6):735-43.

36. Deci EL, Ryan RM. The general causality orientations scale: selfdetermination in personality. J Res Pers. 1985;19(2):109-34.

37. Lepper MR, Greene D, Nisbett RE. Minando o interesse intrínseco das crianças com recompensa extrínseca: um teste da hipótese de "superjustificação". J Pers Soc Psychol. 1973;28(1):129-37.

38. Orsini C, Binnie VI, Wilson SL. Determinants and outcomes of motivation in health professions education: a systematic review based on selfdetermination theory. J Educ Eval Health Prof. 2016;2:13-9.

39. Peixoto JM, Ribeiro MMF, Amaral CFS. Atitude do estudante de medicina a respeito da relação médico-paciente x modelo pedagógico. Rev Bras Educ Med. 2011;35(2)229-36.
40. Hojat $M$, Zuckerman $M$. Personality and specialty interest in medical students. Med Teach. 2008;30(4):400-6.

41. CaiY, Reeve J, Robinson DT. Home schooling and teaching style: comparing the motivating styles of home school and public school teachers. J Educ Psychol. 2002;94(2):372-80.

42. Zenorini RPC, Santos, AAA. A motivação e a utilização de estratégias de aprendizagem em universitários. Estudante universitário: característica e experiências de formação. Taubaté: Cabral Editora e Livraria Universitária; 2003.

43. Williams GC, Deci EL. Internalization of biopsychosocial values by medical students: a test of self-determination theory. J Pers Soc Psychol. 1996;70(4):767-79.

44. Tanaka M, Mizuno K, Fukuda S, Tajima S, Watanabe Y. Personality traits associated with intrinsic academic motivation in medical students. Med Educ. 2009;43:384-7.

45. Kusurkar R, Croiset G, ten Cate O. Implications of gender differences in motivation among medical students. Med Teach. 2013;35(2):173-4.

46. Toledo Júnior ACC, Ibiapina CDC, Lopes SCF, Rodrigues ACP, Soares SMS Aprendizagem baseada em problemas: uma nova referência para a construção do currículo médico. Rev Méd. Minas Gerais. 2008;18(2)123-31.

47. Reeve J. Teachers as facilitators: what autonomy-supportive teachers do and why their students benefit. Elem Sch J. 2006;106(3):225-37.

48. Kusurkar RA, ten Cate TJ, Vos CMP, Westers P, Croiset G. How motivation affects academic performance: a structural equation modelling analysis. Adv Health Sci Educ. 2013;18(1):57-69.

49. Murphy PK, Alexander PAA. Motivated exploration of motivation terminology. Contemp Educ Psychol. 2000;25(1):3-53.

50. Zimmerman BJ. Self-efficacy: an essential motive to learn. Contemp Educ Psychol. 2000;25(1):82-91.

51. Kusurkar RA, Croiset G, ten Cate OTJ. Twelve tips to stimulate intrinsic motivation in students through autonomy-supportive classroom teaching derived from self-determination theory. Med Teach. 2011;33(12):978-982. 